Check for updates

London School of Hygiene and Tropical Medicine, London, UK

Martin.McKee@lshtm.ac.uk Cite this as: $B M J$ 2021;375:n3015 http://dx.doi.org/10.1136/bmi.n3015 Published: 07 December 2021

\section{Misconduct in public office?}

\section{A new report details the case against the Westminster government \\ Martin McKee professor of European public health}

Civil society organisations have a critical role in a democracy, holding governments to account for their actions. This is especially important in the United Kingdom, where the prime minister wields a level of power that is, in comparison with other western parliamentary democracies, quite exceptional, especially when they have a large parliamentary majority. Many of the checks and balances that a US president or German chancellor faces are absent in the UK.

Everyone in the UK who has been touched by the pandemic, and especially those most directly affected such as patients, bereaved family members, and frontline workers in health and other essential services, therefore owes a debt of gratitude to the members of the People's Covid Inquiry, who spent many hours reading and listening to evidence on the Westminster government's handling of the pandemic. ${ }^{1}$ Their 226 page report ${ }^{2}$ sets out in stark detail the many failings that led to the UK having one of the highest death rates in western Europe.

The inquiry panel was assembled by Keep our NHS Public, a group that has long campaigned against underfunding and privatisation of NHS services. Chaired by Michael Mansfield QC, a senior lawyer known as a champion of human rights, it also included Neena Modi, a professor of neonatal medicine and BMA president; Tolullah Oni, an epidemiologist who is also a member of Independent SAGE; and Jacky Davis, a consultant radiologist and founder member of Keep Our NHS Public.

We already know quite a lot about what went wrong in the government's pandemic response. Sources include a series of reports by parliamentary committees, including one that described the initial decisions as among the "most important public health failures that the United Kingdom has ever experienced," 3 and the National Audit Office on the enormous expenditure on a dysfunctional tracing system..$^{4}$ Other insights can be found in accounts by people who had ringside seats, such as Jeremy Farrar and Dominic Cummings, ${ }^{5}$ and in an extremely detailed account by two journalists, Jonathan Calvert and George Arbuthnot, who clearly had first rate sources within and close to the decision making processes. ${ }^{7}$ Health workers such as Dominic Pimenta and Rachel Clarke ${ }^{8} 9$ have described in detail the feeling of being abandoned by the government as they struggled on the NHS frontline.

Many of the findings in this new report will therefore come as no surprise. In his introduction, Mansfield summarises the issues as "lack of preparation and coherent policy, unconscionable delay, through to preferred and wasteful procurement, to ministers themselves breaking the rules." These things we all know. So what does this report add?

Two things in particular stand out. First, it has given a voice to groups whose concerns have been ignored. Time and again witnesses described how their concerns were dismissed by those in authority. They included those struggling to make the system work, such as representatives of teachers, the care sector, and local government. There were others who wanted to help, such as the more than 70 companies that told the BMA they could have supplied high quality personal protective equipment but lacked access to the privileged channels that allowed those with political connections, but often no relevant expertise, to access lucrative contracts. And they included people who had suffered as a consequence of government failings, both from the disease and from the traumatising experience of caring for others while placing their own life at risk.

The report includes many troubling accounts reminding us how each statistic represents the experiences of real people. In a country where parts of the media see nothing wrong with devaluing deaths of children with underlying health conditions ${ }^{10}$ we need to be reminded that all lives are important.

Second, the report places on record the many things that need to be fixed, now with renewed urgency since the arrival of the more transmissible omicron variant. It contains 82 separate recommendations in 15 categories, from education and social care to preparedness and governance. This compilation is especially valuable in showing the range of issues that must be considered by the official inquiry, if and when it finally happens.

Despite this wealth of detail, the report has limitations. It did not take evidence from the government-which was invited but never replied-so cannot yet say why things went so wrong. This should be a major focus of any future public inquiry, whose chair can require anyone to attend to give evidence and produce documents under the 2005 Inquiries Act.

A focus on reasons for failure will only happen if that inquiry is truly independent. The public has good reason to be sceptical, given the government's appointment of supporters to key positions and scouring of social media accounts to exclude people who have ever criticised them..$^{11-13}$ Yet we need answers because covid-19 will not be the last major threat to health. The pandemic has reminded us of longstanding failures of governance in the UK that must be fixed if we are to be prepared for whatever comes next, including an even more lethal 
pandemic. ${ }^{14} 15$ The people's inquiry has identified the many remaining questions-the official inquiry must answer them in a timely, honest and transparent way.

Competing interests: MM gave evidence to the People's Covid Inquiry and has previously written a foreword to a book by Keep Our NHS Public. He is a member of Independent SAGE alongside TO, one of the panel members. He is president elect of the BMA.

Provenance and peer review: Commissioned; not externally peer reviewed.

1 Dyer C. Covid-19: Government was "grossly negligent" in its handling of pandemic, says people's inquiry. BMJ 2021;375:n2955.pmid: 34853055

2 People's Covid Inquiry. Misconduct in public office: why did so many thousands die unnecessarily? 2021. https://www.peoplescovidinquiry.com/

3 Health and Social Care Committee and Science and Technology Committee. Coronavirus: lessons learnt. 2021. https://committees.parliament.uk/work/657/coronavirus-lessons-learnt/news/

4 National Audit Office. Test and trace in England_-progress update. 2021. https://www.nao.org.uk/wp-content/uploads/2021/06/Test-and-trace-in-England-progress-update.pdf

5 Farrar J, Ahuja A. Spike. The virus vs the people, the inside story. Profile Books, 2021.

6 Dominic Cummings: Thousands died needlessly after Covid mistakes. BBC News 2021 May 26. https://www.bbc.co.uk/news/uk-politics-57253578

7 Calvert J, Arbuthnot G. Failures of state: the inside story of Britain's battle with coronavirus. HarperCollins, 2021.

8 Clarke R. Breathtaking. Little, Brown, 2021.

9 Pimenta D. Duty of care. Welbeck, 2020

10 Wise J. Headlines play down the gravity of covid-19 in children. BMJ2021;375:n2826 doi: 10.1136/bmi.n2826 pmid: 34824090

11 Webber E, Casalicchio E. How corrupt is Britain? 2021. https://www.politico.eu/article/greatbritain-boris-johnson-lobby-rules-corruption/

12 Smulian M. Networks banned from inviting speakers critical of government. 2021. https://www.civilserviceworld.com/professions/article/networks-banned-from-inviting-speakerscritical-of-government-policies

13 Outgoing commissioner for public appointments fires warning shot over growing political bias in appointments. 2020. https://www.localgovernmentlawyer.co.uk/governance/396-governancenews/45346-outgoing-commissioner-for-public-appointments-fires-warning-shot-over-growingpolitical-bias-in-appointments

14 Jarman H, Greer SL, McKee M. Brexit is just a symptom: the constitutional weaknesses it reveals have serious consequences for health. J Public Health (Oxf) 2020;42:778-83. doi: 10.1093/pubmed/fdz180 pmid: 31927582

15 European Observatory on Health Systems and Policies. Health systems resilience during covid-19. 2021. https://eurohealthobservatory.who.int/publications/i/health-systems-resilience-duringcovid-19-lessons-for-building-back-better

This article is made freely available for use in accordance with BMJ's website terms and conditions for the duration of the covid-19 pandemic or until otherwise determined by BMJ. You may use, download and print the article for any lawful, non-commercial purpose (including text and data mining) provided that all copyright notices and trade marks are retained. 